\title{
Die resepsie van die Heidelbergse Kategismus (Sondag 17 en 22) insake die opstanding in die Nederduitse Gereformeerde Kerk sedert 2000 (Deel 2)
}

\author{
Author: \\ Johannes W. Hofmeyr ${ }^{1}$ \\ Affiliation: \\ ${ }^{1}$ Department of Church \\ History and Polity, University \\ of the Free State, \\ South Africa \\ Correspondence to: \\ Johannes Hofmeyr \\ Email: \\ linhof@mweb.co.za \\ Postal address: \\ Boardwalk Meander A-216, \\ Olympus, Pretoria 0081, \\ South Africa \\ Dates: \\ Received: 29 Jan. 2013 \\ Accepted: 16 May 2013 \\ Published: 16 Aug. 2013 \\ How to cite this article: \\ Hofmeyr, J.W., 2013, \\ 'Die resepsie van die \\ Heidelbergse Kategismus \\ (Sondag 17 en 22) insake \\ die opstanding in die \\ Nederduitse Gereformeerde \\ Kerk sedert 2000 (Deel 2)', \\ In die Skriflig/In Luce Verbi \\ 47(2), Art. \#690, 9 pages. \\ http://dx.doi.org/10.4102/ \\ ids.v47i2.690
}

\section{Copyright:}

(C) 2013. The Authors. Licensee: AOSIS OpenJournals. This work is licensed under the Creative Commons Attribution License.

Read online:

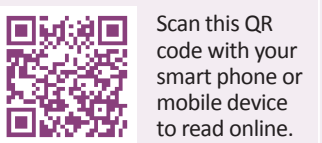

Met die 450e herdenking van die Heidelbergse Kategismus as vertrekpunt, word met die huidige en die vorige artikel gepoog om lig te werp op die plek, die rol en die interpretasie van die opstanding van Jesus Christus in veral Sondag 17 en 22, spesifiek in die konteks van twee besondere eras in die Nederduitse Gereformeerde (NG) Kerk. In die vorige artikel is allereers 'n bespreking gevoer oor die Heidelbergse Kategismus (HK). Daar is gekyk na die resepsie van die betrokke HK-geloofsartikels in die era van Andrew Murray, spesifiek teen die agtergrond van die negentiende-eeuse liberale teologie in Nederland. In die huidige artikel word soortgelyk gekyk na die resepsie van die betrokke HK-geloofsartikels in die NG Kerk na 2000, teen die agtergrond van die herverskyning van die negentiende-eeuse liberale teologie in die vorm van die Jesus Seminaar, die Nuwe Hervorming en ondersteuners daarvan binne die NG Kerk. Sowel die negentiende-eeuse liberale stryd in die NG Kerk asook die stryd oor die opstanding in die NG Kerk van die eerste dekade van die een-en-twintigste eeu, soos verder in hierdie artikel sal blyk, was gekenmerk deur kontekstueelbepaalde uniekhede. Die gemene deler was dat albei deel was van tye van teologiese vrysinnigheid. In die lig van hierdie bespreking word tot die gevolgtrekking gekom dat die NG Kerk tans, betreffende haar identiteit as gereformeerde kerk waarskynlik in 'n kritieke geloofs- en toekomskrisis verkeer. Dit impliseer kommerwekkende gevolge vir haar Skrifverstaan en getuienis as belydenis en belydende kerk van Jesus Christus en haar toekoms. Alleen duidelike visie, verantwoordelike leierskap en 'n herontdekking van die verlossingskrag van Christus se kruis en opstanding sal herstellende, positiewe en dinamiese oplossings kan bied om sodoende die NG Kerk te red van 'n snelwentelende afwaartse spiraal.

The reception of the Heidelberg Catechism (Sunday 17 and 22) with regard to the resurrection within the Dutch Reformed Church since 2000 (Part 2). With the 450th celebrations of the origin of the Heidelberg Catechism (HC) in mind, the main aim of this and the previous article is to focus on the place, role and interpretation of the doctrine of the resurrection in HC (Sunday 17 and 22), within two very specific and critical eras in the history of the Dutch Reformed Church (DRC) in South Africa. The first article focused on the reception of the HC in the time of Andrew Murray during the nineteenth century, and specifically against the background of the then liberal theology in both the Netherlands and South Africa. In this current article I look at the reception of the same HC articles (Sunday 17 and 22) in the DRC after 2000, against the background of the reappearance of the nineteenth century liberal theology in the Netherlands, and specifically with reference to the Jesus Seminar, the New Reformation and those sympathetic to the latter in the DRC. Both these nineteenth- and twenty-first-century developments had their own unique contexts but what they had in common were a specific theological liberal mindset. In view of this discussion it is concluded that the DRC as a reformed church is not only caught up in an identity crisis, but even in a survival crisis of no small proportions. This also has serious implications for its use of Scripture and its confessional character. Only strong vision, able leadership and a rediscovery of the redeeming power of the cross and resurrection of Christ will be able to provide a remedial, positive, and dynamic solution, saving the DRC from an ever downward spiral.

\section{Inleiding}

Wanneer daar in hierdie herdenkingsjaar ook in Suid-Afrika teruggedink word aan die wêreldwye plek, rol en funksie van die Heidelbergse Kategismus (HK) in die loop van 450 jaar, word onwillekeurig nagedink oor hoe die NG Kerk standpunt ingeneem het oor verskillende sake in hierdie dokument, synde een van sy drie belydenisskrifte. Onlangs het sommige teoloë hierdie belydenisskrifte sodanig geherinterpreteer dat hulle oorspronklike betekenis en bedoeling verlore gaan, terwyl ander geleerdes so ver gaan om kategories te verklaar dat die belydenisskrifte geen nut meer het nie, omdat die inhoud daarvan klaarblyklik nie meer met hulle teologiese nadenke vereenselwig kan word nie. Hierdie ontwikkelings is nie net aantoonbaar uit die standpunte en werke van teoloë en bybelwetenskaplikes buite die kerk nie, maar inderdaad ook binne die NG Kerk. Onder sommige NG-kerkleiers, -teoloë en -bybelwetenskaplikes is daar tans 'n neiging om sogenaamde nuwe 
wetenskaplike insigte in so 'n mate te omarm dat die hart van ons belydenisse sodanig verwaarloos of geherinterpreteer word dat die wesenlike binding met die Vroeë Kerk, die Skrif en God drie-enig, tragies genoeg, in gevaar gestel word.

Die rede agter die bespreking in die vorige artikel van die liberale teologie van die negentiende eeu in Nederland en Suid-Afrika, en die teologiese ontwikkelings in die NG Kerk in die eerste dekade van die een-en-twintigste eeu in hierdie artikel, is daarin geleë dat die onderliggende vertrekpunte oor God, Christus, die belydenis en die wetenskap in hierdie twee eras merkwaardige ooreenkomste toon, alhoewel daar ook kontekstuele verskille is. Die bedoeling is glad nie om op 'n polemiese of ad hominem wyse die NG Kerk of enige individue in die beskuldigdebank te plaas nie. $\mathrm{Al}$ is daar vanweë die nabyheid van die gebeure moontlike subjektiwiteite in die waarnemings en bevindings, behoort hierdie ontwikkelings en standpunte tog wel so gebalanseerd moontlik aan die lig gestel te word. Hierdie oorsig kom ook op geen manier uit 'n rigiede konteks waarin die belydenisse of dogma van die kerk verheerlik word ten koste van 'n klem op die leer én lewe en 'n behoorlike ernsmaking met die nuutste insigte van die geestes- en ander wetenskappe nie. Aan die ander kant durf die NG Kerk egter nie in die slaggat van 'n ongebalanseerde beklemtoning van ortopraksie ten koste van ortodoksie te trap nie. Hierdie artikel moet gelees word teen die agtergrond van bepaalde eensydige wetenskaplike ontwikkelings wat alreeds sedert die negentiende eeu in Nederland aangetref is en nou, weliswaar in ' $n$ ander vorm, in die Jesus Seminaar en die Nuwe Hervorning 'n herlewing beleef. Hierdie laasgenoemde twee bewegings het veral in sekere kringe van die NG Kerk en die Nederduitsch Hervormde Kerk 'n besliste aanhang. Wanneer ontwikkelings in die eerste dekade van die een-en-twintigste eeu in die NG Kerk vervolgens aan die orde gestel word, is dit vanuit hierdie raamwerk en perspektiewe en beslis op geen manier bedoel om bepaalde individue af te kraak nie.

\section{Die een-en-twintigste-eeuse Nederduitse Gereformeerde Kerk en die opstanding}

\section{Inleidend: Konflik oor die liggaamlike opstanding in die Nederduitse Gereformeerde Kerk}

De iure is Sondag 17 (en 22) van die HK in 2012 nog steeds geldend in die NG Kerk, nie net wat die bewoording betref

\footnotetext{
1.Dit is nie moontlik om in ' $\mathrm{n}$ beperkte artikel soos hierdie, die twintigste-eeuse teologiese montwikkelings in die NG Kerk wat tussen die negentiende en een-enteologiese ontwikkelings in die NG Kerk wat tussen die negentiende en een-entwintigste eeue sorteer, aan die orde te stel nie. Daar sou uiteraard'n hele bespreking gevoer kon word oor die Du Plessis-saak van die twintigerjare van die vorige eeu. Laasgenoemde saak kan belangrike aspekte aan die orde stel, maar die kompleksiteit aan so ' $n$ bespreking is byna legio. Een voorbeeld is voldoende. Sakkie Spangenberg, stigter van die sogenaamde Nuwe Hervorming in 2004 (wat later bespreek word), verwys telkemale in openbare lesings na die besonder belangrike rol wat Du Plessis gespeel het in die ontginning van die kritiese Bybelwetenskap en die onhoudbaarheid wat dit vir die belydenisskrifte tot gevolg het. Daar word ook soms in dieselfde asem na die apartheidsteologie van die NG Kerk verwys en geargumenteer dat indien die kritiese Bybelwetenskap reeds vroeër ernstig geneem was, die NG Kerk moontlik nie die weg van apartheid sou gegaan het nie. Hierdie hipotese het egter ernstige tekortkomings, omdat wat die politiek betref, Du Plessis volgens alle aanduidings nie aan die ver-linkse kant was nie; die gewaarwording dat apartheid of afsonderlike ontwikkeling nie teologies regverdigbaar is nie, het hoofsaaklik nie vanuit die $\mathrm{Ou}$ en Nuwe-Testamentiese Bybelwetenskaplikes se insigte na Suid-Afrika gekom nie. en Nulle Hulle was sonder twyfel van die eerste vakgebiede wat erns met die opkoms van die kritiese insigte van die Bybelwetenskappe gemaak het. Daardie gewaarwordings het aanvanklik uit die geledere van die kerkhistorici en dogmatici gekom, waaronder B.B. Keet, Ben Marais, Beyers Naudé, en andere, alhoewel ' $n$ verskeidenheid teoloë uit uiteenlopende vakdissiplines later bygekom het. Dat daar belangrike sake deur die Du Plessis-saak op die tafel geplaas is, is inderdaad so. Dit is met baie energie seder die sewentigerjare van die twintigste eeu deur 'n aantal teoloë opgetel, waaronder W.S. Vorster en A.B du Toit, om net enkeles te noem.
}

nie, maar ook die betekenis en interpretasies daarvan. Daar was nog geen besluite van 'n verteenwoordigende, oorkoepelende kerklike vergadering om die teendeel te besluit nie. In 2003 het die Algemene Sinodale Kommissie (ASK) van die NG Kerk opnuut bely, in ooreenstemming met die hoe van die opstanding en die implikasies daarvan soos dit in Sondag 17 en 22 bely word, dat die 'werklike, liggaamlike, historiese opstanding uit die dood' (die hoe) 'die kern van ons geloof' is (die implikasie). Dit staan bekend as die herbevestiging van die NG Kerk se amptelike standpunt na aanleiding van die nuut-gestigte sogenaamde Nuwe Hervorming. Laasgenoemde ontken byvoorbeeld die liggaamlike opstanding van Jesus en dit word later in hierdie artikel meer breedvoerig bespreek.

Uiteindelik blyk dit dat die ASK-verklaring van 2003 heelwat reperkussies gehad het. In 'n sterk bewoorde reaksie het drie vooraanstaande NG-teoloë van Pretoria, James Kirkpatrick ('n belangrike rolspeler in die kuratorium-dagbestuur by UP en later voorsitter van AKLAS), Fanie Cronjé, en ook Eduan Naudé hulle misnoeë met die ASK-verklaring uitgespreek. Dieselfde jaar het die Noordelike Sinode, met Kobus Gerber as moderator, Pieter Craffert en Pieter Botha van Unisa, twee stigterslede van die Nuwe Hervorming, genooi om die Sinode toe te spreek. Die uiteindelike gevolg was dat die Sinode nie 'n kategoriese geloofsbelydenis oor die geskiedkundigheid van Jesus se liggaamlike opstanding wou maak nie. Volgens koerantberigte het James Kirkpatrick 'n sleutelrol in hierdie besluit gespeel deurdat hy tydens die Sinode gepleit het vir ruimte om nie meer die 'ortodokse geloofstaal van die kerk' na te sê nie. Kobus Gerber, wat toe die moderator van die betrokke sinode was en tot en met 2007 die voorsitter van die Kuratorium by UP was, is sedertdien in 'n sleutelposisie in die NG Kerk aangestel, te wete as Algemene Sekretaris.

Hierdie kontrasterende gebeure van 'n amptelike bevestiging van die NG Kerk se belydenis oor Jesus se liggaamlike opstanding tot ernstige besware daarteen, was in der waarheid net een van 'n hele aantal ontwikkelings wat uiteindelik 'n groot teologiese stryd in die eerste dekade van die een-en-twintigste eeu in die NG Kerk geword het.

Hierdie paar inleidende gebeure (wat deurlopend met $\mathrm{HK}$, Sondag 17 en 22 verbind kan word) voorsien 'n mens van ' $n$ aantal belangrike hermeneutiese vertrekpunte om die stormagtige teologiese woelings in die eerste dekade van die een-en-twintigste-eeuse NG Kerk te verstaan en te interpreteer - hiervan was die outeur 'n naby waarnemer. Met laasgenoemde in gedagte, help die volgende paar vrae om die besprekings wat volg, ook met betrekking tot die belydeniskwessies, te stuur:

- Wie en wat is die sogenaamde Nuwe Hervorming?

- Hoekom het die NG Kerk op daardie stadium besluit om amptelik en in die openbare mediastandpunt in te neem oor Jesus se liggaamlike opstanding?

- Wanneer, hoe, deur wie en in watter vorms het teenstand teen laasgenoemde ontwikkel?

- Wanneer, hoe en deur wie het HK, Sondag 17 (en later ook Sondag 22) deel geword van die debat oor die opstanding?

Hierdie vrae is ' $n$ poging om duidelike vertrekpunte daar te stel, naamlik om 'n aantal gebeure wat hoofsaaklik sedert 
2000 ontwikkel het, aan die orde te stel; om as tematiese vertrekpunte te dien om die gebeure te interpreteer; en om ook as klankbord te dien om uiteindelik oor die toekoms van die NG Kerk na te dink, met spesifieke verwysing na HK, Sondag 17 en 22. Hierdie punte en ook die vier vrae hierbo, word nie puntsgewys sistematies hanteer nie, maar hulle dien as hermeneutiese agtergrond wat deurentyd in gedagte gehou kan word soos die beredenering ontwikkel.

\section{Die Jesus Seminaar en die Nuwe Hervorming: Utrecht en Leiden se negentiende-eeuse liberalisme herbesoek die Nederduitse Gereformeerde Kerk}

Met die 2003-gebeure rondom die NG Kerk se ASKverklaring oor Jesus se liggaamlike opstanding en die Nuwe Hervorming as agtergrond, is ' $n$ paar opmerkings ten opsigte van die aanloop tot en die eerste reaksies op hierdie gebeure van pas.

In die twee dekades voor die aanbreek van die een-entwintigste eeu het ' $n$ relatief ou liberale teologiese stroom, met sy wortels in die negentiende-eeuse Europese liberalisme, 'n herlewing in die VSA beleef. Met Bybelwetenskaplikes soos Robert Funk, John Dominic Crossan, Burton Mack, Marcus Borg, Lloyd Geering, Walter Wink, John Selby Spong, Don Cupit en ook die Suid-Afrikaanse Hervormde teoloog Andries van Aarde aan boord, is 'n beweging, die Jesus Seminaar, in 1980 gestig. Alhoewel dit 'n klein minderheid in die bybelwetenskaplike wêreld verteenwoordig het, was dit gesofistikeerd en het dit met groot mediaveldtogte die aandag getrek. Op die spoor van die werk van D.F. Strauss (vgl. sy invloed in die negentiende eeu op Scholten in Leiden), Rudolf Bultmann met sy 'ontmitologiseringsprogram'2 en andere, het hierdie groep met groot sensasie seminare in Amerika gehou waartydens 'n Jesus gepopulariseer is, soortgelyk aan die Jesus wat 'n mens in Opzoomer en Scholten in die negentiende eeu in Nederland gevind het. Natuurlik was daar ook verskille en die Jesus Seminaar was gewis meer gesofistikeerd, gegewe onder meer die ontdekking van geskrifte soos die Gnostiese evangelie van Thomas en ander nie-kanonieke geskrifte. Met hulle basiese vertrekpunt, is hierdie egter die herontdekking van 'n negentiendeeeuse Jesus wat volgens bepaalde en eksklusiewe rasionele modelle geïnterpreteer word. Hierdie Jesus kon geen wonders doen nie, was nooit maagdelik verwek nie en het nie liggaamlik uit die dood opgestaan nie. Gevolglik het net sy morele voorbeeld, gelykenisse en ander wyshede oorbly. ${ }^{3}$ Met dit as agtergrond het die ASK-verklaring oor die Nuwe Hervorming in 2003 onder meer die volgende uitspraak oor die Jesus Seminaar en hulle 'radikale historiese metode' gemaak:

Jesus het (vir diegene - JWH) ... daarom nie letterlik uit die dood uit opgestaan nie, bevind die radikale historiese metode. So ook met Jesus se geboorte uit 'n maagd. 'n Meisie wat nog

2.Wat die Afrikaaanse teologiese landskap betref, is die werk van Flip Schutte, 'n student van Andries van Aarde wat uiteindelik uit die Hervormde Kerk bedank het, waarskynlik die beste verteenwoordiger van Bultmann se 'ontmitologiseringsprogram' (vgl. die beste verteenwoordiger
Schutte 2008:30-41, 72-136)

3. Hierdie samevatting is uiteraard' $n$ oorvereenvoudiging. Vir' $n$ genuanseerde bespreking, sien Wright (1999:83-120) en Janson (2001:58-77). nooit gemeenskap met ' $n$ man gehad het nie, kan nie 'n baba kry nie. Dit kon daarom ook nie in Jesus se tyd met Jesus gebeur het nie. En die wonders van Jesus kon ook nie plaasgevind het nie.

Hiermee saam het die panenteïsme se god wat in alles is (wat alreeds by Opzoomer van Utrecht in die negentiende eeu te vind was en dus glad nie nuut is nie) ook weer in verskillende gedaantes ' $n$ herlewing beleef in die werke van onder meer Marcus Borg (1997), Walter Wink (1997) en Cupit en Miller (2007:122-134). Alhoewel daar dus etlike verskille tussen die Jesus Seminaar en die negentiende-eeuse liberalisme is wat in Opzoomer van Utrecht en Scholten van Leiden te vind is, was daar ook merkwaardige ooreenkomste. Schalk $\mathrm{du}$ Toit se kriptiese opsomming van die negentiende-eeuse liberalisme in Utrecht en Leiden, kan net sowel oor ' $n$ paar basiese vertrekpunte van die Jesus Seminaar gesê word. In Du Toit (2008) se opsomming kan ook sommige insigte van die Jesus Seminaar raakgesien word:

... die Bybel is die weergawe van mense se belewenis van hulle godsdiens; Christus was 'n besonder begaafde mens; God gryp nie in die loop van sake in nie en dus is daar nie sprake van wonders nie; die wetenskap en gepaardgaande wysbegeerte is die manier waarop tot die waarheid gekom word en die kritiese metode waarmee alle aansprake op waarheid getoets moet word. Uiteindelik is 'n mens se toewyding in godsdiens 'n persoonlike saak waarmee jy jou eie menswees help ontwikkel tot ' $n$ verligte en opgevoede mens wat op humanistiese wyse 'n positiewe bydrae tot die samelewing maak. (bl. 8)

In die lig van die gebeure rondom die Jesus Seminaar, het 'n paar NG-Bybelwetenskaplikes (hoofsaaklik van Unisa) waaronder die prominente Sakkie Spangenberg, Pieter Craffert, Pieter Botha, en 'n voormalige Hervormer Hansie Wolmarans van die Universiteit van Johannesburg (RAU op daardie tydstip), veral sedert 2000 elkeen op sy eie manier hierdie gebeure as die katalisator vir'n soortgelyke beweging (die Nuwe Hervorming) hier in Suid-Afrika gesien. 'n Verskeidenheid voorafgaande teologiese ontwikkelings in Suid-Afrika het die grond help voorberei vir hierdie beweging wat laasgenoemde teoloë in die vooruitsig gestel het. Hier volg enkele voorbeelde:

- Danie Veldsman, latere NG-dosent in Dogmatiek by UP en wat ook'n sleutelrol gespeel het in die onskuldigbevinding aan leerdwaling van Julian Müller en Jurie le Roux in 2006, het alreeds in 1993 in 'n Hervormde Teologiese Studies (HTS)artikel selfstandig met die gedagte geëksperimenteer dat Jesus nie 'liggaamlik' uit die dood opgestaan het nie; dat die kanoniese evangelies ' $n$ 'legendariese' karakter het; en dat van Jesus se dissipels moontlik sy dooie liggaam herbegrawe het (Veldsman 1993:987-2008).

- Dieverskyning van dieHervormdeKerken JesusSeminaarteoloog Andries van Aarde se opspraakwekkende boek, Fatherless in Galilee (2000) het baie spanning in die Hervormde kerk veroorsaak en kan selfs in 2012 gedeeltelik verantwoordelik gehou word vir 'n moontlike kerkskeuring). ${ }^{4}$

- Die verskyning van Ben du Toit, jarelange voorsitter van die NG Kerk se Algemene Sinode Kommissie vir Leer en

4.Sien byvoorbeeld die uitgebreide besprekings hieroor by Ferdie Mulder (2011:56$60,212-232$ ) en ook Andries van Aarde oor kerkskeuring (Van Aarde 2012). Wat laasgenoemde betref, is die saak natuurlik meer kompleks, maar ' $n$ bespreking daarvan val buite die bestek van hierdie artikel. 
Aktuele Sake (AKLAS), se veelbesproke boek, God? Geloof in 'n postmoderne tyd? (2000). Sakkie Spangenberg was die seremoniemeester tydens die bekendstelling daarvan by Unisa. ${ }^{5}$

- Julian Müller, sedert 2000 departementshoof in Praktiese Teologie aan UP, se openbare uitsprake oor die Jesus Seminaar sedert $2000 .^{6}$

- Besonderlik ook die besoek van John Dominic Crossan van die Jesus Seminaar aan UP in 2002, as persoonlike gas van Andries van Aarde. Spangenberg, die meesterbrein agter die Nuwe Hervorming het later aangedui dat Crossan se besoek instrumenteel was in die totstandkoming van die Nuwe Hervorming (Mulder 2011:25).

Uiteindelik is die Nuwe Hervorming gestig (amptelik eers in 2004, maar onoffisieel reeds in 2003). 'n Aantal boeke oor hulle insigte het verskyn, landswye seminare is gehou en sensasionele en volgehoue publisiteit in die media het gevolg.

Veral by UP het 'n paar NG-teoloë, wat simpatiekgesind was teenoor onder meer Spangenberg se navorsing en insigte, begin om oop-gesprekke en nadenke oor die insigte van die Jesus Seminaar en die Nuwe Hervorming te stimuleer. Julian Müller, wat in sekere NG-kringe besonder invloedryk is, het al sedert 2000 akkommoderende uitsprake oor die Jesus Seminaar in die konteks van Jesus se opstanding begin maak en later ook ten opsigte van die panenteïsme. Jurie le Roux het tydens ' $n$ openbare lesing oor die Nuwe Hervorming by Unisa in 2003, sy waardering vir Andries van Aarde se Fatherless in Galilee uitgespreek. Hy het ook in die openbaar aangetoon dat hy alreeds as NG-teoloog by UP die standpunt 'op sy eie manier' gestel het dat 'n mens nie meer Jesus se opstanding 'letterlik' hoef te bely nie (Mulder 2011:212-217).

Veral sedert 2003 het verdeeldheid oor wesenlike teologiese sake onder NG-dosente en -studente skerp begin toeneem. Dit is belangrik om daarop te wys dat dit nooit die geval was dat een groep erns gemaak het met die nuutste ontwikkelings in die onderskeie wetenskappe, teenoor 'n ander groep wat dit nie gedoen het nie. Die verdeeldheid het grotendeels ontstaan in die konteks van die wetenskaplike metodes en uitkomste van die Jesus Seminaar en die Nuwe Hervorming. Bekommerde teoloë se probleme was dus hoegenaamd nie geleë in die blootstelling aan kritiese denke as sodanig nie; dit was eerder dat kerklike teoloë van Tukkies standpunte ingeneem het wat nie meer met die hart van die evangelie versoenbaar was nie en inderdaad ook nie met die NG Kerk se legitimasieverklaring nie. 'n Voorbeeld wat iets hiervan illustreer, kom uit die pen van Hennie Stander wat van verskeie gesprekke met studente in die jare 2000-2003 vertel. Hy was destyds departementshoof in Antieke Tale van die Fakulteit Geesteswetenskappe by UP:

Voor my sit 'n derdejaar student. Wanneer hy begin praat, sien ek sy oë swem in trane: 'Professor, ek wil met u praat. Ek worstel

5.Volgens Jan van der Watt, Stephan Joubert, Jan du Rand en Adrio König (2001) verwerp 'Du Toit ... Bybelse perspektiewe op die bonatuurlike (bv, die wonders, die duiwel en die maagdelike geboorte)', en alhoewel hy die opstanding aanvaar, 'kry (hy) dit reg deur die opstanding self wesenlik te verander'.
(n)

6.In 'n preek, 'Protestants is om in Jesus te glo', wat op die internet gepubliseer is, het Müller alreeds in 2000 gepleit vir ruimte om Jesus se opstanding 'letterlik' ó 'metafories' te bely. Die Jesus Seminaar bely dit ook. met my geloof. Hoe kry u dit nog reg om in Jesus te glo?' Ek kan nie onthou hoeveel teologie studente in die afgelope twee jaar in my kantoor kom sit het met dieselfde vraag nie. Later begin die student onbeskaamd snik en sê: 'Professor, ek voel soos 'n verraaier. Tuis in my ouerhuis glo ek saam met my ouers en is ek aktief betrokke in ons gemeente, maar wanneer ek hier by die universiteit kom, word baie van die dinge waarin ek glo, in die klas met minagting afgelag.' Skielik dink ek aan dit wat iemand op 'n keer vir my gesê het: 'Die teoloë leef met die geld van gelowiges, maar hulle ondergrawe die geloof van dieselfde gelowiges.'Hierdie stelling is baie skerp, maar bevat dit nie tog 'n element van waarheid nie? Maar wat antwoord ek die studente wat met hulle vrae kom? Wel, ek sê vir hulle: 'Bly vashou aan die geloof wat al in jou ouma Loïs en in jou ma Eunice was, en wat, daarvan is ek oortuig, ook in jou is.' Akademici het beslis nie die laaste sê wanneer dit by geloofsake kom nie. (Stander 2002)

Heelwat meer kan genoem word wat die stelselmatige akkomoderende houding betref jeens die metodes en insigte van die Jesus Seminaar en die Nuwe Hervorming by veral UP, maar bogenoemde kursoriese momente (en ook die gebeure voorafgaande tot die ontstaan van die Nuwe Hervorming hierbo genoem), gee genoeg agtergrond om nou die vrae oor HK, Sondag 17 en 22 in die konteks van die eenen-twintigste-eeuse gesprekke oor die opstanding in die NG Kerk onder die loep te neem. Die vraag is wanneer, hoe en deur wie het HK, Sondag 17 en 22 deel geword van die debat binne die NG Kerk oor die opstanding.

\section{Heidelbergse Kategismus, Sondag 17 in die Nederduitse Gereformeerde Kerk-gesprek oor die opstanding: Die insigte van Julian Müller}

Die antwoord op die vraag oor wanneer HK, Sondag 17 deel geword het van die gesprek oor die opstanding in die NG Kerk, kan gevind word in 'n Oop Gesprek radio-uitsending van RSG wat op 29 Mei 2005 by die NG Kerk Kameeldrif buite Pretoria opgeneem en die daaropvolgende Sondagaand nasionaal uitgesaai is. Hierdie opname staan in die teken van woelings wat veral UP 'n hoogtepunt bereik het, deurdat meer en meer NG-teoloë, -predikante en -teologiese studente ernstige vrae begin vra het oor die groeiende tendens om die insigte van die Jesus Seminaar en die Nuwe Hervorming by UP te akkommodeer.

Skynbaar het die radiogesprek op versoek van die Teologie Fakulteit by UP plaasgevind. Deelnemers aan die gesprek het onder meer Julian Müller namens UP, Kobus Gerber namens die kuratorium, en George Nel van NG Kerk Booysens in Pretoria ingesluit. Voor die gesprek, so het dit later geblyk, is ' $n$ lys van ongeveer tien vrae aan deelnemers beskikbaar gestel sodat hulle hulself goed kon voorberei vir die program. Uit hierdie vrae was daar ook een spesifieke vraag wat met Jesus se opstanding verband gehou het. 'n Vraag oor Jesus se opstanding sou dus hoegenaamd nie buite die orde of onverwags kon gewees het nie (Mulder 2011:53).

$\mathrm{Na}$ aanleiding van besprekings tydens die program oor die kommer wat daar onder sommige predikante en lidmate heers oor die rigting waarin UP se teologiese fakulteit beweeg, het George Nel besluit om nie ongetoetste bewerings oor 
teologiese liberalisme by UP te maak nie, maar eerder by Müller self te hoor wat hy oor Jesus se opstanding glo. Nel het aan Müller gevra of hy glo dat Jesus liggaamlik uit die dood opgestaan het en of dit beteken dat die graf leeg was? Müller wou nie bevestigend of ontkennend op die vraag antwoord nie en het soos volg gereageer:

Ek het vanoggend ' $n$ erediens bygewoon soos wat ek elke oggend ' $n$ erediens bywoon op 'n Sondag. En met groot vrymoedigheid sê ek met die gemeente saam die Apostolicum, want dit is wat ek glo ... dit beteken nie dat daar nie ruimte vir herinterpretasie is nie.

Teologiestudente en sommige teoloë was ongemaklik oor Müller se vae belydenis oor die opstanding tydens hierdie radiogesprek. Müller het toegegee: 'Sommige het my kwalik geneem en gesê ek het 'n gulde geleentheid laat verbygaan om te getuig van my geloof in die opstanding' (Müller 2006:8). Uitsprake wat Müller alreeds vroeër oor die opstanding gemaak het, was deels verantwoordelik vir die ongemak. Na aanleiding van die radiogesprek het die Sondagkoerant Rapport op 12 Junie 2005 'n verklaring van vyf NG-studente (onder leiding van 'n voorgraadse student Cobus van Wyngaard) gepubliseer waarin hulle hul algehele ondersteuning aan al die UP-dosente toegesê het. Beeld het ook op 25 Junie 2005 berig oor 'n verklaring oor Jesus se liggaamlike opstanding wat opgestel was deur Ferdie Mulder (voormalige Deo Gloria-voorsitter) en ander senior studente. Dit was onderteken deur 46 studente van UP. In voetnotas onder aan die verklaring was aanhalings uit artikels en/of gesprekke met Julian Müller, Jurie le Roux, Dirk Human (NG-dosente van UP), Ben du Toit (toe AKLASvoorsitter in die Kaap) en Louis Jonker (toe 'n NG-dosent van Stellenbosch) met wie hulle verskil het.

In die hitte van hierdie teologiese stryd het Müller die dekaan spesiaal versoek dat hy al die NG-studente by UP wil toespreek tydens 'n weeklikse godsdiensperiode. Die gesprek het op 28 Julie 2005 plaasgevind. Juis hierdie lesing bring ' $n$ mens by die belang van HK, Sondag 17, omdat Müller laasgenoemde as ' $n$ hermeneutiese sleutel in sy gesprek oor die opstanding gebruik het. Ferdie Mulder, 'n meestersgraadstudent wat ook die geleentheid bygewoon het, vat die hoofmomente in die aanloop tot die bespreking van die HK tydens die gesprek, redelik goed saam:

Dit het relatief duidelik in professor Müller se lesing na vore gekom dat hy diegene wat sterk voel oor Jesus se liggaamlike opstanding en leë graf, verdink het van 'n uitgediende teologie wat werk met 'formules' wat 'stol', wat 'isoleer', en wat 'onaantasbaar' is ... Teenoor diegene wat besorg was oor die liggaamlike opstanding het hy sy interpretasies en geloof in die opstanding beskryf as 'kreatief', 'onversadigbaar soekend', 'vry' en deel van 'n 'nuwe taal'. (Mulder 2011:97)

Met dit ter agtergrond word uit Müller se lesing aangehaal, sodat hy nie buite konteks aanhaal word wat sy interpretasie van die opstanding in die HK betref nie:

In my eie verstaan en verwoording van my geloof in die opgestane Heer, het ek my nog altyd sterk laat lei deur die benadering van die Heidelbergse Kategismus. Dit is sekerlik nie sonder betekenis nie dat die Kategismus uit die 129 vrae en antwoorde, net een enkele vraag en antwoord aan die opstanding afstaan (vraag 45). En al wat gevra word is: 'Watter nut het die opstanding van Christus vir ons?' Daar word nie gevra na of gespekuleer oor die fisiese opstanding van Christus nie ... In plaas daarvan word daar besin oor die metaforiese of figuurlike betekenis van die opstanding ... Ek voel my in goeie geselskap. Die aanklagte wat teen my ingebring is, sal definitief ook teen die Heidelbergse Kategismus ingebring moet word, want die Leermeester het nagelaat om die woorde 'historiesfisies' te gebruik in sy verwoording van die opstandingsgeloof. (Müller 2005)

In die lig van die negentiende-eeuse liberalisme van veral Opzoomer van Utrecht, waar die ortodoksie verruil was vir ortopraksie, is Müller se klem tydens die lesing op die opheffing van die samelewing belangrik, in teenstelling met wat hy sien as energie wat aan ortodokse praatjies gemors word:

Ek is kwaad daaroor dat ek moet redeneer, argumenteer en selfs verdedig oor die korrekte bewoording van 'n geloofskonstruk ... Ek dink dis tragies dat teologiese studente en dosente hulle energie aan ortodokse praatjies moet bestee, terwyl honderdduisende mense daarbuite vasgevang is in die greep van die verskriklikste armoede en werkloosheid; doodgaan aan Vigs. $^{7}$ (Müller 2005)

Voor verdere besprekings na aanleiding van bogenoemde, net een korreksie. Die vraag wat George Nel aan Müller gevra het tydens die radiogesprek was nie in verband met die histories-fisiese opstanding nie, maar insake die liggaamlike opstanding, wat natuurlik ooreenkom met HK, Sondag 22 (later meer oor lg.).

\section{Die opstanding maar nie die liggaamlike opstanding van die Heidelbergse Kategismus nie}

Een van die argumente waarvoor Müller bekendheid in die NG Kerk verwerf het, is die teorie dat die belydenisskrifte (en ook die HK) 'sober' en 'ekonomies' met die opstanding van Jesus omgaan. In sy boek, Opstanding, skryf Müller dat hy protesteer teen wat hy beskou as die byvoeg van woorde soos 'fisiek' of 'liggaamlik'. Dít, oordeel hy, doen afbreek aan die 'misterie-karakter' van die opstanding en staan in die teken van 'n evangeliese fundamentalisme (Müller 2006:10). Die belydenisskrifte getuig klaarblyklik van die opstanding van Jesus, nié van die liggaamlike opstanding nie. 'n Goeie voorbeeld wat dit illustreer, is Müller se reaksie op 'n briefskrywer in Die Kerkbode in 2005. In die konteks van die RSG-radiogesprek waartydens hy nie bevestigend of ontkennend wou antwoord op die vraag oor die liggaamlike opstanding nie, stel die briefskrywer dit soos volg: 'As u die vraag of Jesus Christus liggaamlik (d.w.s. fisies) uit die dood en die graf opgestaan duidelik en ondubbelsinnig antwoord, sal niemand u meer kan misverstaan nie.' (Anon. 2005). Müller het hierop gereageer deur te beweer dat die woorde liggaamlik en fisies, op die belydenisskrifte wil verbeter wat ook 'juis afbreek doen aan die misterie-karakter van die opstanding'. Müller sluit sy verduideliking soos volg af: 'U byvoegings verteenwoordig ' $n$ afwyking van die suiwere

7.Die bestek van hierdie artikel laat nie toe om Müller se klem op die ortopraksie ten koste van die ortodoksie te bespreek nie en daarom net een tersaaklike opmerking. Sommige van die teologiestudente wat die verklaring oor Jesus se liggaamlike opstanding opgestel het waarin Müller se standpunte verwerp word, was vir jare opstanding opgestel het waarin Müller se standpunte verwerp word, was vir jare
lank tydens hulle teologiese opleiding betrokke by ' $n$ plakkerskamp waar ' $n$ HIVlank tydens hulle teologiese opleiding betrokke by 'n plakkerskamp
kliniek ontwikkel is, asook'n kinderhuis in Pretoria (Mulder 2011:99). 
verstaan van die opstanding. Daarom antwoord ek nooit daarop ja nie!' (Müller 2005).

Voordat gekyk word na enkele teologiese vertrekpunte agter Müller se verstaan van die opstanding, eers 'n insiggewende opmerking ten opsigte van die opstanding in die HK.

\section{Müller, Mulder en die liggaamlike opstanding in die Hedelbergse Kategismus, Sondag 17 en 22}

In die outeur se navorsing aangaande Müller se argumente vir 'n sober en ekonomiese opstanding in die HK, het hy etlike response daarop bestudeer, insluitend Adrio König se boek, Die evangelie is op die spel (2008), Attie van Niekerk (2009) se omvangryke artikel, D.G. van der Merwe (2006) se resensie en tientalle besprekings in koerante. Interessant genoeg was daar een persoon wat vroeg reeds agtergekom het dat HK, Sondag 22 ook in sy breë betekenis deur Müller buite rekening gehou word. ${ }^{8}$ Ferdie Mulder, die student wat tot 'n groot mate die leier agter die 2005-studenteverklaring was, skryf na aanleiding van Müller se verstaan van die opstanding in HK, Sondag 17 soos volg:

Die Heidelbergse Kategismus (word) ongelukkig deur professor Müller gebruik ... om te probeer aantoon dat daar heel sober oor die opstanding gepraat word ... (die HK) het egter 'n verrassende mooi en aangrypende deel oor die liggaamlike opstanding van beide gelowiges en Jesus in Vraag 57 (Mulder 2011:118).

Inderdaad is dit wel so. Dit is dus 'n redelike moontlikheid dat Müller se protes eintlik ook 'n protes, veroordeling en afkeur van HK, Sondag 22 is. Hy het 'n emotiewe afkeur en selfs veroordeling van dit wat hy bestempel as evangeliese en fundamentalistiese Christene (Müller 2006:10) se aandrang op die liggaamlike opstanding. Die HK, Sondag 22 het redelik uitgebreide en aangrypend verduidelikings van die liggaamlike opstanding van gelowiges en Jesus. Sondag 22 sê onder meer dat 'nie alleen my siel na hierdie lewe dadelik tot Christus, sy Hoof, opgeneem sal word nie, maar ook hierdie selfde liggaam'.

Dit wil egter voorkom asof Müller nie die HK se formulerings ten volle begryp nie, en vervolgens ook nie genoegsaam kennis geneem het van die ireniese en positiefgereformeerde Zacharias Ursinus, die hoofsamesteller van die $H K$, se uitgebreide kommentaar op die HK nie. Ursinus was 'n prominente leerling van Philip Melanchton en is ook diepgaande deur hom beïnvloed. Ursinus is as Heidelbergse professor in die Dogmatiek veral bekend vir sy De libro Concordiae ('n strydgeskrif teen die Lutherse Formula Concordiae) en sy Explicationes Catecheticae (Kommentaar op die Kategismus; Ehmann 2013:105-116; Bierma 2013:31-40). Uit verbatim-aanhalings uit die Kommentaar van Ursinus op die Kategismus blyk dit wat volg byvoorbeeld baie duidelik. Ter wille van groter toeganklikheid word die goeie Engelse vertaling van die Latynse teks deur Williard (1852) gebruik.

Oor die hoe van Christus se opstanding is Ursinus by Vraag en Antwoord 45 (Sondag 17) baie uitgesproke. Aan die een kant is dit duidelik dat Christus met 'n verheerlikte en getransformeerde liggaam uit die graf opgestaan het (Ursinus, 1956:Pt. IV, 7). Aan die ander kant skryf Ursinus:

And truly nothing different from that which had died, could rise again. The very same body, therefore, which had fallen a victim to death rose again; and it is this which affords us such great comfort ... Yea, had not the flesh of Christ risen, ours could not rise. [En niks anders as wat doodgegaan het, kan weer opstaan nie. Hierdie selfde liggaam wat doodgegaan het, herleef weer; en dit is wat ons soveel gemoedsrus gee... Indien die liggaam van Christus nie opgewek is nie, kan ons liggaam ook nie opgewek word nie.] (Pt II, 2, [outeur se eie vertaling])

Ursinus (1956) gaan voort en sê:

Because it was proper that his body should rise free from corruption, and yet not so soon after his death as to leave any doubt that he was truly dead. It is for this reason that he rose on the third day, and not on the first. [Omdat dit gepas is dat sy liggaam sonder gebrek opgewek word, en nie so gou na sy dood sodat daar enigsins twyfel kon ontstaan het of Hy waarlik dood was nie. Dit is die rede waarom Hy op die derde dag opgewek is.] (Pt II, 4. [outeur se eie vertaling])

Ursinus handhaaf dus op 'n gebalanseerde wyse die skriftuurlike balans tussen kontinuiteit én diskontinuiteit deurdat dieselfde liggaam van Christus wat aan die kruis gehang het uit die graf gekom het. Hy was egter tegelykertyd getransformeerd en verheerlik.

Met betrekking tot die sogenaamde soberheid en ekonomiese formulerings van HK, Sondag 17 (uitgesluit 22) mag Müller korrek wees met betrekking tot die teks self, maar oor die intensie daarvan kan daar vanuit Ursinus se Kommentaar geen twyfel wees oor wat Ursinus werklik bedoel het nie, naamlik die liggaamlike opstanding. Müller beweer, soos vroeër aangedui is, dat die HK nie na die liggaamlike opstanding vra nie, maar eerder besin oor die 'metaforiese of figuurlike' betekenis daarvan. Müller voel hom daarom met sy sogenaamde 'suiwere verstaan' in goeie geselskap en meen dat daarom ook aanklagte teen die HK ingebring kan word. Wanneer die Ursinus-Kommentaar egter oor die nut van die opstanding (wat van sentrale belang vir Müller is) handel, is dit duidelik dat die belydenis oor die opstanding nie uitsluitlik om 'n metaforiese nie, maar ook oor 'n liggaamlike betekenis handel:

What then is the meaning of this article of the Creed: I believe in Christ who rose from the dead on the third day? It means that I believe: (1) That Christ did truly recall his soul to his body which was dead, and quickened it. (2) That he retained a true soul and body, and that both are now glorified, and free from all infirmity. (3) That he rose by his own divine virtue and power. (4) That he rose for the purpose of making us partakers of the righteousness, holiness, and glorification, which he had purchased for us. [Wat is die betekenis van hierdie artikel van die belydenis: Ek glo in Christus wat op die derde dag uit die dood opgewek is? Dit beteken dat ek glo: (1) Dat Christus waarlik sy siel na sy liggaam, wat dood was, laat terugkom het en dit weer lewendig laat word het. (2) Dat Hy'n ware siel en liggaam behou het, en dat albei nou verheerlik is, vry van alle krankhede. (3) Dat Hy deur sy eie goddelike voortreflikheid en krag opgewek is; (4) Dat Hy opgewek is om ons deelgenote te maak van die regverdigheid, heiligheid en verheerliking wat Hy vir ons verwerf het.] (Ursinus 1956, Pt IV , 7, [outeur se eie vertaling]) 
Wanneer dit gaan oor Sondag 22, Vraag en Antwoord 57 wat oor die troos van Jesus se opstanding vir die gelowige handel, is die Ursinus-Kommentaar nogeens uitgesproke oor die liggaamlike opstanding. Die opstanding volgens die Kommentaar:

\begin{abstract}
... will consist, first in the restoration of the same body, or the bringing together the mass or matter which now constitutes our bodies, but which, after death, is scattered, and dissolved in different elements. Secondly, it will consist in the re-union of the body with the same soul which it had at first, by which it will also be quickened, and be made immortal. [... sal in die opstanding eerstens uit dieselfde liggaam bestaan, of die liggaamsmaterie waaruit ons liggame nou bestaan en wat moontlik na ons dood versprei of in verskillende elemente opgeneem mag wees, weer saamvoeg. Tweedens sal dit bestaan in die hereniging van die liggaam met dieselfde gees (siel) wat dit aanvanklik gehad het en wat nou weer lewendig en onsterflik gemaak sal word.] (Ursinus 1956, Pt III, [outeur se eie vertaling])
\end{abstract}

In reaksie op verskillende dwalings van sy tyd sê Ursinus vervolgens in sy Kommentaar:'In opposition to all these errors, it becomes us to believe what the Scriptures affirm in relation to this subject, that the dead will most certainly rise again.' [Teenoor al hierdie dwalings glo ons wat die Skrifte aan ons bevesting in verband met hierdie onderwerp, dat die dooies sekerlik weer sal opstaan.] (Ursinus 1956, Pt III). In Pt V herhaal Ursinus dit:

The bodies with which we shall rise in the resurrection, will not only be human bodies, but also the very same which we now have, and not other and different bodies created by Christ. Finally, as Christ rose with the same body which he had when he died, so shall we also rise with the very body which we now have. [Die liggame waarmee ons sal opstaan in die opstanding sal nie net menslike liggame wees nie, maar dieselfde liggame wat ons nou het en nie ander of verskillende liggame wat Christus sal skep nie. Ten slotte: soos Christus met dieselfde liggaam as waarmee Hy gesterf het, opgewek is, so sal ons ook met dieselfde liggaam opstaan as wat ons nou het.] [outeur se eie vertaling] Tot hier die Kommentaar oor die HK wat Ursinus daargestel het.

Bogemelde toon die verskille tussen Ursinus en Müller se interpretasies van die opstanding duidelik in die HK aan. Vir laasgenoemde is daar geen sprake van die liggaamlike opstanding van Jesus of gelowiges in die HK nie, terwyl Ursinus, die meesterbrein agter die HK, telkens die klem op die liggaamlike opstanding plaas. Dit is nie net sy Kommentaar wat die bedoeling van die HK onderstreep nie, maar ook HK, Sondag 22 self; maar Müller ignoreer hierdie.

\section{Is daar ruimte binne die Heidelbergse Kategismus, Sondag 17 en 22 vir die Jesus Seminaar en die Nuwe Hervorming se radikale interpretasies?}

Attie van Niekerk, 'n gerespekteerde sendingwetenskaplike van UP, skryf in 'n omvangryke artikel (Van Niekerk 2009:320-348) soos volg: 'Müller beweer meermale dat sy kritici sy standpunt so verkeerd formuleer, dat hy onbillik en selfs kwaadwillig aangeval word. Sy kritici mag dalk voel dat dieselfde met hulle gedoen word.' (Van Niekerk

9.Billikheidshalwe is'n nota oor 1 Korintiërs 15:37 nodig. Paulus skryf wel dat die saad wat in die grond sterf, nie die plant is wat uit die saad opgroei nie. In 1 Korintiërs wat in die grond sterf, nie die plant is wat uit die saad opgroei nie. In 1 Korintiers
15 vind ons sowel kontinuitteit as diskontinuiteit. Die soort diskontinuiteit wat 'n mens by die Jesus Seminaar en die Nuwe Hervorming vind, beweeg egter ver verby Paulus en die Skrif. Ongeag watter vrugbare gesprekke 'n mens oor kontinuïteit en Paulus en die Skrif. Ongeag watter vrugbare gesprekke ' $n$ mens oor kontinuïteit en diskontinuïteit kan voer, is die belangrikse saak in hierdie artikel dat die HK in
erns maak met die liggaamlike opstanding, wat Müller kategories ontken.
2009:321). Die saak waarom dit hier gaan, is onder meer die vraag na die belydenisskrifte en of hulle die liggaamlike opstanding bely, en ook of hulle eerder ekonomies en sober die opstanding verwoord? $\mathrm{Na}$ 'n gedetailleerde en ongetwyfeld genuanseerde dialogiese omgang met Müller se werk, wat etlike persoonlike gesprekke insluit, skryf Van Niekerk soos volg: 'Dit is ... nie so maklik om aan die einde te weet wat hy presies glo nie!' (Van Niekerk 2009:345).

Oor liggaamlike opstanding, fisieke opstanding, historiese opstanding of net opstanding, is daar male sonder tal die afgelope aantal jare gepraat en geskryf. Gesprekke hieroor het grootliks in 'n doodloopstraat geëindig. Wat dalk meer sinvol kan wees, om ons moontlik agter die kap van die byl te bring, is om te kyk hóé Müller oor die Jesus Seminaar en die Nuwe Hervorming se verstaan van die opstanding skryf en nadink; en of sy teorie van 'n sober en ekonomiese opstanding, soos hy nadink oor HK 17 en ook die ander belydenisskrifte, ruimte bied vir húlle interpretasies oor die opstanding.

Dit is belangrik om daarop te let dat Müller uitdruklik skryf dat hy nie 'n Nuwe Hervormer is nie. Hy pleit egter gereeld vir 'n gesprek met laasgenoemde groepering, en op hierdie stadium is dit nie duidelik in watter mate hy met sommige aspekte van hulle interpretasies saamstem of verskil nie. Billikheidshalwe aanvaar ' $n$ mens Müller se uitspraak, en jy wil hom daarom ook nie 'n Nuwe Hervomer maak nie! Hoe dit ookal sy, sy uitsprake oor laasgenoemde en ook die Jesus Seminaar in die konteks van die opstanding en die belydenisskrifte, mag dalk help om beter te verstaan wát die reikwydte van Müller se interpretasie oor die opstanding in $\mathrm{HK}$, Sondag 17 is, en wat die implikasies daarvan vir die NG Kerk is. Van die belangrikste openbare uitsprake wat Müller oor die jare in hierdie verband gemaak het, is kortliks die volgende:

- In 2000 skryf Müller spesifiek met betrekking tot 'behoudende' teoloë en die Jesus Seminaar, dat dit nie werklik saak maak of 'n mens die opstanding letterlik of metafories glo en bely nie. Wat belangriker is, is of 'Jesus die Here' is (Müller 2006:68). Jesus is dus Here ongeag of Hy letterlik óf metafories uit die dood opgestaan het. ${ }^{10}$ Indien 'n mens hom hierin reg verstaan, weerspreek hy Romeine 8:11 en 10:9-10 waar geloof in die opstanding aan ons verlossing en spesifiek die liggaamlike opstanding verbind word (asook HK, Sondag 22).

- In 2003 bespreek Müller by Skuilkrans NG Kerk sy eie 'spirituele reis' van 'oriëntasie, disoriëntasie en heroriëntasie' voor 'n groot gehoor NG-predikante met onder meer Pieter Craffert en Pieter Botha van die Nuwe Hervorming teenwoordig. Hy stel 'n nuwe soort 'padkaart' aan die einde voor na aanleiding van sy ervarings waaronder blootstelling aan die Colombia Theological Seminary waar 'definitief al die dosente ... nie 'n letterlike verstaan en geloof in die ... opstanding onderskryf nie'

10.In hoofstuk tien in Müller se Opstanding verwys hy weer na die ekonomiese en sober bewoording van ons belydenisskrifte wanneer dit oor die opstanding handel. Hy verklaar: ' $[b]$ eide die skeptiese natuurwetenskaplike én die mistieke dromer kan saam sê: "Ek glo in die opstanding", terwyl hulle waarskynlik heel verskillende kan saam sê: "Ek glo in die opstanding", terwyl hulle waarskynlik heel verskillende
konsepte daarop nahou' (Müller 2006:89). Vroeër in dieselfde hoofstuk gee Müller konsepte daarop nahou' (Müller 2006:89). Vroeër in dieselfde hoofstuk gee Müller
toe dat die skeptiese wetenskaplike twyfel oor die bonatuurlike aard van onder meer die opstanding (Müller 2006:87). 
(Müller 2006:19-27). Na aanleiding van die lesing verklaar Willem Nicol tydens die paneelbespreking die volgende: '... enige iemand (is) nou welkom ... om predikant in die NG Kerk te word, ook diegene wat Jesus se letterlike opstanding uit die dood verwerp' (Mulder 2011:150).

- Tydens die UP-dissiplinêre verhoor wat Müller, Jurie le Roux en Dirk Human saam met Cas Vos (toe dekaan) geïnisieer het teen Ferdie Mulder, is Müller se antwoord op die vraag of die NG Kerk se belydenisskrifte ruimte bied vir die Nuwe Hervorming se standpunt dat Jesus 'nie letterlik' uit die dood opgestaan het nie, soos volg: 'Ek glo so. Ek dink soos wat die NG Kerk en sy teologie ontwikkel op die oomblik is dit veel meer inklusief as eksklusief en die klem val daarop om na mense te luister ...' (Mulder 2011:186).

- Mulder berig dat daar later tydens die verhoor weer spesifiek na die Nuwe Hervormers se ontkenning van Jesus se liggaamlike opstanding verwys is; die 2003 Algemene Sinodale Kommissie-verklaring van die NG Kerk waarin Jesus se liggaamlike opstanding bely word en die ontkenning daarvan verwerp word en die onsuksesvolle gesprekke wat senior NG-leiers wel met lede van die Nuwe Hervorming gehad het. Volgens die verbatim wat die universiteit beskikbaar gestel het, was Müller se reaksie op hierdie gesprekke soos volg: 'Dit is tog jammer né?' Dit is die rede waarom Mulder in die lig hiervan tereg soos volg daarop reageer: 'Ooglopend wou Prof Müller nie die NG Kerk se afkeur van die Nuwe Hervorming se verstaan van die opstanding aanvaar nie' (Mulder 2011:187).

\section{Nadenke oor die toekoms van die Nederduitse Gereformeerde Kerk met spesifieke verwysing na die Heidelbergse Kategismus, Sondag 17 en 22}

Die bestek van ' $n$ artikel soos hierdie maak nie voorsiening vir 'n omvangryke en gedetailleerde bespreking van al die redes waarom hierdie tipe denke veral in die NG Kerk grondgevat het en wat al die moontlike toekomstige implikasies vir die NG Kerk in die lig van die voorgaande bespreking oor HK, Sondag 17 en 22 is nie. Slegs enkele opmerkings word gemaak in die lig van die voorafgaande besprekings. Sommige van die moontlike redes waarom hierdie denke spesifiek ook in die NG Kerk ontwikkel het, is waarskynlik omdat daar enersyds 'n veelvuldigheid van aksente binne die NG Kerk bestaan wat relatief gemaklik geakkommodeer word. Andersyds was daar ook binne die konteks van die nuwe Suid-Afrika en die postmodernisme gedurende die afgelope paar dekades al meer 'n relatief kritieklose blootstelling aan ander teologiese standpunte binne sowel as buite Suid-Afrika.

In die Skrif word die liggaamlike opstanding van Christus (en van gelowiges in die toekoms) onlosmaaklik met ons heel eenvoudigste en basiese belydenis verbind. In Romeine 8:11 beskryf Paulus dat gelowiges se sterflike liggame op grond van Christus se opwekking weer lewend gemaak sal word; en in Romeine 10:9 verklaar hy 'As jy met jou mond bely dat Jesus die Here is, en met jou hart glo dat God Hom uit die dood opgewek het, sal jy gered word.' In hierdie belydenis lê die allerheiligste kern van ons geloof asook ons verlossing, met die gepaardgaande ryk implikasies daarvan. Dieselfde fokus op die liggaamlike opstanding en die implikasies daarvan vind 'n mens aangrypend in HK, Sondag 17 en 22.

In hierdie artikel het die outeur op die herlewing van 'n soortgelyke liberale teologiese stroom gefokus wat soos in die negentiende eeu in Nederland, ook nou sedert 2000 in onder andere die NG Kerk'n opbloei beleef. In die huidige oplewing is die Jesus Seminaar en die Nuwe Hervorming prominent, asook sommige NG-teoloë wat op grond van laasgenoeomde groeperings se insigte óf ernstige probleme ondervind met die liggaamlike opstanding in ons belydenisskrifte (vgl. HK, 17 en 22), óf bloot pleit vir 'n ekonomiese en sober verstaan van die opstanding wat HK 22 totaal buite rekening laat. Wat verloor 'n mens indien jy die liggaamlike opstanding van HK 22 buite rekening hou en ruimte binne ons belydenis vind vir die radikale interpretasies van die Jesus Seminaar en die Nuwe Hervorming?

Die steeds invloedryke Van Ruler uit Nederland, wat op die hoogste vlak oor die bomenslike en misteriekarakter van die toekomstige opstanding nagedink het, skryf soos volg in sy boek, Blij zijn als kinderen - Een boek voor volwassenen: '... werkelijk alles samenloopt in het artikel van de opstanding van het vlees. Wie dit artikel laat vallen, laat het hele christelijke geloof uiteenvallen' [... alles loop saam in die artikel van die opstanding van die liggaam. Wie hierdie artikel laat verval, laat die hele Christelike geloof uitmekaarval'] (Van Ruler 1972:146). Van Ruler se uitspraak was nie net in ooreenstemming met die Skrif en ons belydenisskrifte nie, dit was ook profeties van wat in die hoofstroom protestantse kerke in Nederland sedert veral die middel van die twintigste eeu gebeur het. Met Harry Kuitert en ander vrysinnige teoloë aan die voorpunt, het die populêre siening posgevat dat dit nie meer nodig is om Jesus se liggaamlike opstanding te glo en te bely nie. Uiteraard is daar ' $n$ hele aantal uiteenlopende redes wat aangevoer kan word vir die afwaartse spiraal wat kerke in Nederland vandag kenmerk. Dit is egter duidelik dat die omarming van die soort liberalisme wat'n mens in die negentiende eeu en daarna aldaar gevind het, uiteindelik 'n bydraende faktor was in die vernietiging van die protestantse kerke in Nederland. Is dieselfde tans besig om ook in die NG Kerk in Suid Afrika te gebeur met die opkoms van en akkommodering van die insigte van die Jesus Seminaar en die Nuwe Hervorming? Gegewe die uiteensettings in hierdie artikel, wil dit ongelukkig so voorkom.

\section{Slot}

Daar is nog 'n hele aantal getuienisse wat 'n mens sou kon behandel, maar bovermelde is genoegsaam om ' $n$ mens ' $n$ aanduiding te gee van die ontwikkelings en standpunte binne die NG Kerk oor die opstanding van Jesus sedert 2000. Aan die een kant is daar diegene wat met gedeeltelike aansluiting by die Jesus Seminaar en die Nuwe Hervorming ernstige probleme het met die liggaamlike opstanding, deur onder meer die teorie te ontwikkel dat die HK sober en ekonomies oor die opstanding handel; dat die HK nie die liggaamlike opstanding propageer nie; en dat daar uiteindelik ook 
ruimte is vir die Jesus Seminaar en die Nuwe Hervorming se ontkenning van die liggaamlike opstanding binne die NG Kerk se verstaan van die belydenisskrifte. Aan die ander kant is daar diegene (waaronder die 2003-ASK) wat nie minder erns gemaak het met die nuutste ontwikkelings in die geestesen ander wetenskappe nie, maar inderdaad steeds wil vashou aan die liggaamlike opstanding van Jesus soos wat dit onder andere in HK, Sondag 17 en 22 aan ons voorgehou word. Vir hulle vorm dit die hart van ons belydenis en verlossing.

Daar was wel kontekstueelbepaalde verskille tussen die soort liberale teologie wat ' $n$ mens in die negentiendeeeuse stryd in die NG Kerk gekry het. Sommige van die hoofrolspelers was Opzoomer, Kotze en Burgers aan die een kant en Murray aan die ander kant. Die herlewing hiervan was in ' $n$ nuwe gewaad in die vorm van onder meer die Jesus Seminaar, die Nuwe Hervorming en diegene wat laasgenoemde stromings binne die belydenisgrondslag van onder meer HK, Sondag 17 en 22 wil akkommodeer. Die hoofrolspelers hier was onder andere Spangenberg, Van Aarde en Müller aan die een kant en König, Mulder en andere aan die ander kant. Die ooreenkomste is egter merkwaardig dieselfde en getuig ten minste daarvan dat die sogenaamde nuwe wetenskaplike insigte en stromings van die negentiende en ook die een-en-twintigste-eeu nie kan of wil aanvaar dat die God van die heelal, sy natuurwette deurbreek het om Jesus, die Seun van God liggaamlik uit die graf op te wek nie. Met dit in gedagte, is daar geen beter manier om hierdie artikel mee af te sluit nie as om met hoë agting te luister na Willie Jonker (1987) (wat in Suid Afrika én Nederland hoogleraar was) se raak beskrywing van die moderne mens se afkeur in Jesus se liggaamlike opstanding en hoe hy ons ewige verlossing daarmee verbind:

Waarom is dit vir die Christelike geloof so belangrik om vas te hou aan die liggaamlike opstanding van Jesus uit die graf? Kan ons dit nie maar op 'n geestelike wyse interpreteer om die besware van die wetenskaplike moderne mens tegemoet te kom nie ... Dit is nie eers die moderne mens wat probleme ondervind het met die liggaamlike opstanding van Jesus nie. Wat dit betref, was die mense in Bybelse tye ook al merkwaardig modern. Die verhale oor die opstanding was vir hulle van huis uit net so ongeloofwaardig as vir mense van ons dag ... Die opstanding van Christus is die radikale nuwe daad en wonder van God ... Daarom is die liggaamlike opstanding van Christus deel van die hart van die evangelie. Ons verlossing staan en val daarmee ... (25 April)

\section{Erkenning Mededingende belange}

Die outeur verklaar dat hy geen finansiële of persoonlike verbintenis het met enige party wat hom nadelig kon beïnvloed in die skryf van hierdie artikel nie.

\section{Literatuurverwysings}

Anon., 2005, 'UP Teologie-studente', Die Kerkbode, 25 Augustus.

Bierma, L.D., 2013, 'The origins of the threefold structure of the Heidelberg Catechism: Another look', in K. Apperloo-Boersma \& H.J. Selderhuis (eds.), Power of faith: 450 years of the Heidelberg Catechism, pp. 31-40, Vandenhoeck\& Ruprecht, Göttingen.

Borg, M., 1997, The God we never knew: Beyond dogmatic religion to a more authentic contemporary faith, Harper, New York.

Cupit, D. (ed.) \& Miller, R.J., 2007, The future of the Christian tradition, Polebridge, Salem.

Du Toit, B., 2000, God? Geloof in 'n postmoderne tyd, CLF-Uitgewers, Bloemfontein. PMCid:91984

Du Toit, S., 2008, God ons Vader en die Kerk ons Moeder?, besigtig 30 November 2012 vanaf http://www. ngkok.org.za

Ehmann, J., 2013, 'The Heidelberg Catechism in its Palatine homeland', in K. ApperlooBoersma \& H.J. Selderhuis (eds.), Power of faith: 450 years of the Heidelberg Catechism, pp. 105-116, Vandenhoeck \& Ruprecht, Göttingen.

Janson, M., 2001, Op soek na die ware Jesus, Lux Verbi, Wellington.

Jonker, W.D., 1987, 'Jesus se opstanding', Die Burger 25 April.

König, A., 2008, Die evangelie is op die spel, Lux Verbi, Wellington.

Mulder, F., 2011, Opgestaan, Opgestaan Publikasies, Cambridge.

Müller, J.C., 2000, Protestants is om in Jesus te glo, besigtig 29 November 2012, vanaf http://www.pvr.co.za/preke/Julian290kt.htm

Müller, J.C., 2005, Opstandingsgeloof: Lesing van Augustus 2005, besigtig 29 November 2012, vanaf www.teo.co.za

Müller, J.C., 2006, Opstanding, Lux Verbi, Wellington.

Schutte, F., 2008, Jesus' resurrection in Joseph's garden, Protea Book House, Pretoria. Stander, H., 2002, 'UP-Teologie-studente', Kerkbode, 06 September.

Ursinus, Z., 1956, The commentary of Zacharias Ursinus on the Heidelberg Catechism, Translated from the original Latin by the Rev. G.W. Williard, Eerdmans, Grand Rapids.

Van Aarde, A., 2012, Kerkskeuring, besigtig 29 November 2012, vanaf http://www. steedshervormers.co.za/verklarings-steedshervormers/111-persverklaring-2maart-2012.html

Van der Merwe, D.G., 2006, Opstanding, Verbum et Ecclesia 27(2), 772-774.

Van Niekerk, A.A., 2009, 'Die stryd oor die opstanding aan die Teologiese Fakulteit by UP: 'n Gesprek met prof Julian Müller', Verbum et Ecclesia 30(1), 320-348. http:// dx.doi.org/10.4102/ve.v30i1.76

Van Ruler, A.A., 1972, Blij zijn als kinderen - Een boek voor volwassenen, Kok, Kampen.

Veldsman, D.P., 1993, 'Die opstanding van Jesus: God se nadergekome en steeds naderkomende protes en liefde', Hervormde Teologiese Studies 49(4), 987-1008.

Wink, W., 1997, The powers that be: Theology for a new millennium, Doubleday Books, New York. PMCid:2224050

Wright, N.T., 1999, 'Five gospels but no gospel: Jesus and the seminar', in B. Chilton \& C.A. Evans (eds.), Authenticating the activities of Jesus, Brill, Leiden. 